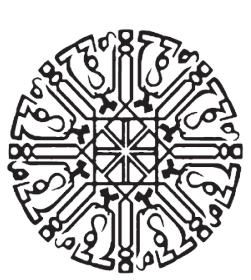

\title{
Objektifikasi Qișās dan Diyat: Sebuah Tawaran Pembaharuan KUHP
}

\author{
Akhmad Sulaiman, Nur Ikhlas \\ IAIN Purwokerto \\ akhmadsulaiman14@gmail.com,nurikhlas099@gmail.com
}

\begin{abstract}
The reporting media indicates that the killing ceses in Indonesia keep on rise. It means that applying killing criminal law that refers to KUHP is not effective. This condition requires KUHP reforming because the right of human life must be vouched by the government. The criminal law of Indonesia must punish a killer more forceful. The writers offer qișās and diyat to be applied in Indonesia but they have to pass through objectification. According to Kuntowijoyo, objectification is interpreting religion's internal doctrines into objective categories in order to be able to be applied, actualized, and accepted by moslem and nonmoslem. It is research and development that strives for developing Kuntowijoyo's objectification on KUHP reforming. With changing qișās term into die punishment, diyat into compensation for victim's family, and adjusting with objective condition in Indonesia, qișās and diyat will be accepted by every national of Indonesia and become solution of criminal law of Indonesia that is not effective.
\end{abstract}

Key words: objectification, qișās, KUHP reforming

\section{Pendahuluan}

Hukum pidana yang berlaku di Indonesia merujuk kepada Kitab Undang-undang Hukum Pidana (KUHP). Kitab Undang-undang Hukum Pidana, sebagaimana dijelaskan dalam UU No. 1 Tahun 1946 pasal 4, merupakan nama lain dari Wetboek van Strafrech (WvS). Teks asli WvS/KUHP hinga kini masih berbahasa Belanda dan tidak ada terjemah resmi yang keluarkan pemerintah (Bahiej, 2005: 16). KUHP merupakan rujukan hukum pidana Indonesia yang telah berlaku sejak 1918. Keberadaan KUHP telah menghapus hukum-hukum adat yang telah berlaku sebelumnya (Reksodiputro, 2016,:3). 
Jamaa (2016: 262) menyebutkan bahwa segala jenis hukum, termasuk hukum pidana, memiliki dua fungsi yaitu social control dan social engineering. Social control berarti bahwa hukum harus mampu menjadikan individu terintegrasi ke dalam masyarakat sedangkan social engineering merupakan sarana untuk menggerakan masyarakat dan merubah perilaku masyarakat menuju keadaan yang ideal. Ketika hukum belum mampu memeranakan dua fungsi tersebut, perlu dilakukan reformasi dan pembaharuan hukum.

Berdasarkan data yang penulis kumpulkan, hukum pidana yang merujuk pada KUHP tidak mampu menjalankan fungsinya sebagai social control dan social engineering. Detik (2015) mengabarkan bahwa pada tahun 2015 telah terjadi kenaikan angka kasus pembunuhan 4\%. Memasuki awal 2016, pembunuhan juga meningkat. IPW (Indonesian Police Watch) menyatakan bahwa ada 34 orang meninggal karena pembunuhan (Fokus Jabar, 2016). Liputan6.com (2017) melaporkan bahwa di Sumatera Selatan telah terjadi 6 pembunuhan sadis pada 2017.

Reformasi KUHP mendesak untuk dilakukan mengingat hak hidup dan memperoleh rasa aman merupakan hak setiap warga negara. Penulis menawarkan hukuman qișāș dan diyat untuk diterapkan di Indonesia sebagai pengganti hukuman penjara yang terbukti tidak efektif. Qișāṣ dan diyat telah terbukti efektif sebagai sarana penjamin kehidupan (hifẓ alnafs). Pada tahun 1975, Arab Saudi yang menerapkan qișās dan diyat dimasukan ke dalam daftar Nations not Obsessed with Crime. Sam S. Souryal, seorang professor dari Amerika, awalnya bersikap skeptis dengan menganggap data tersebut tidak akurat hingga pada tahun 1983-1984 dia melakukan penelitian di Arab Saudi dan beberapa negara Timur Tengah lainnya hingga akhrinya dia menyakini bahwa syariat itu efektif. (Topo Santoso, 2003: 135).

al-Zuḥaili (1985: 260) menyebut qișāṣ sebagai al-'uqūbah al-așliyyah (sanksi pidana pokok). Ketika ada alasan tertentu seperti pemberian maaf dari pihak keluarga atau pembunuhan dilakukan secara tidak sengaja, maka qișāș tidak diberlakukan dan beralih ke al-'uqūbah al-badaliyyah (sanksi pengganti) yaitu diat dan/atau takzir. Karena alasan ini, konsep qișāṣ dan diyat ibarat dua sisi mata uang yang tidak bisa dipisahkan.

Penerapan hukuman qișāṣ dan diyat harus didahuli proses objektifikasi. Objektifikasi merupakan gagasan epistemologi-metodologis yang ditawarkan Kuntowijoyo untuk menguniversalkan ajaran agama agar dapat diterima oleh setiap orang. Ini penting untuk dilakukan di negara-bangsa dan pluralis warganya (Munfarida, 2015:141). Obektifikasi dapat dijadikan sebagai solusi baru untuk mengintegrasikan hukum Islam ke ranah publik tanpa harus berbenturan dengan kelompok nasionalis-sekuler yang anti terhadap segala wacana berbau agama dalam ranah publik. Objektifikasi hukum Islam dapat dijadikan sebagai jalan tengah agar ajaran-ajaran Islam dapat diterima semua golongan.

Penelitian ini tergolong penelitian dan pengembangan (Research and Development). Research and Development adalah metode penelitian yang digunakan untuk menghasilkan

al-ạ̣kām Vol. 3, Nomor 1, 2018 
produk tertentu (Sugiono, 2009: 407). Penelitian ini berusaha untuk mengkaji pemikiran Kuntowijiyo mengenai objektifikasi. Penelitian ini tidak berhenti pada deskripsi dan analisis mengenai Objektifikasi tetapi deskripsi dan analisis ini menjadi langkah awal untuk mengobjektifkan qișāș dan diyat sebagai bentuk produk hukum positif. Penelitian mengenai pemikiran ini diawali dengan mengumpulkan data dari karya Kuntowijoyo yang menjelaskan mengenai objektifikasi yaitu buku Islam sebagai IImu dan Identitas Umat Islam (sumber primer) dan referensi-referensi lain sebagai tambahan informasi (sumber sekunder). Kemudian, untuk memperoleh gambaran rinci mengenai qișāș dan diyat, penulis menggunakan kitab fikih perbandingan yaitu al-Figh al-Islāmi wa Adillatuhu karya Wahbah al-Zuhaili karena kitab ini merupakan kitab fikih perbandingan yang paling komprehensif dengan tambahan data dari kitab-kitab fikih lain. Tujuannya adalah untuk mengetahui pendapat-pendapat fikih yang paling sesuai kondisi masyarakat Indonesia yang plural. Setelah terpilih pendapat-pendapat yang sesuai, langkah akhir dari penelitian ini adalah mengobjektifkan qișāș dan diyat dengan alur berpikir yang dibuat Kuntowijoyo.

Berdasarkan pencarian di berbagai online respository, penulis tidak menemukan sama sekali penelitian mengenai objektifikasi qișāṣ dan diyat. Penelitian relevan yang penulis temukan adalah pertama makalah M. Khoirul Hadi dkk (2016:199-237) dalam Jurnal Yudisia yang berjudul Objektifikasi Hukum Perkawinan Islam Di Indonesia PerspektifMaqasid Syar'iyyah Upaya dari Keilmuan Keislaman. Setelah penulis membaca isi dari makalah ini, penulis malah menyimpulkan judul makalah ini tidak sesuai dengan isinya. Judul lebih tepat menggunakan istilah formalisasi atau positivisasi hukum perkawinan Indonesia, bukan objektifikasi. Dalam hal judul, penelitian ini memiliki kesamaan dengan penelitian penulis karena sama-sama mencoba mengaitkan konsep objektifikasi Kuntowijoyo dengan hukum Islam hanya saja berbeda ranah yaitu antara ranah hukum perkawinan dengan hukum pidana.

Kedua, penelitian Miftahuddin dkk (2014) yang berjudul Kuntowijoyo dan Pemikirannya: Dari Sejarahwan sampai Cendekiawan. Penelitian ini menjawab 3 rumusan masalah yang salah satunya mengenai kontribusi pemikiran Kuntowijoyo sebagai seorang cendekiawan. Penelitian yang objek kajiannya luas ini hanya sedikit membahas konsep objektifikasi. Dengan demikian, penelitian ini hanya mengenalkan konsep objektifikasi sedangkan penelitian penulis berusaha mengembangkan konsep objektifikasi.

Ketiga, makalah Elya Munfarida (2015: 131-144) dalam Jurnal Komunika yang berjudul Reinterpretasi Islam Integratif: Objektifikasi Deliberatif Islam di Ruang Publik. Makalah ini berupaya mengawinkan konsep objektifikasi Kuntowijoyo dengan Deliberasi Jurgen Gobermas dengan tujuan akhir memberi tawaran epistemologis agar nilai-nilai Islam dapat diimpelentasikan ke dalam kehidupan publik dan berperan aktif dalam konstruksi identitas bangsa. Penelitian ini berusaha mengembangkan konsep objektifikasi dalam 
wilayah yang luas sedangkan penelitian penulis lebih terfokus dan kongkrit dalam masalah hukum pidana.

\section{Objektifikasi : Upaya Universalisasi Ajaran Internal Agama}

Objektifikasi merupakan sebuah tawaran yang epistemologi-metodologis dari Kuntowijoyo. Objektifikasi disinggung dalam dua karya Kuntowijoyo yaitu Identitas Politik Umat Islam dan Islam sebagai IImu: Epistemologi, Metodelogi dan Etika. Sebagai sebuah tawaran dan wacana, istilah objetifikasi juga merupakan istilah baru meskipun maknanya bisa dipahami. Dalam bahasa Indonesia, ketika kata diakhiri dengan "asi", maka kata tersebut menunjukan makna proses atau upaya seperti kata komunikasi, liberalisasi, dan spesialisasi. Jika kita mencari istilah objektifikasi dalam KBBI, maka kita tidak akan menemukannya. Begitu pula dalam Kamus Bahasa Inggris Indonesia, John Echols dan Hassan Shadily (2014: 500 ) hanya menyebutkan kata object $(n)$, objection ( $n$ ), objectionable (adj.), objective (n/ adj.), objectivity (n), dan objector ( $n$ ) dalam karya kamus mereka.

Dalam tradisi bahasa, pada umumnya kata yang berakhiran "asi" dalam Bahasa Indonesia atau "ion" dalam Bahasa Inggris, sebagaimana telah disinggung di atas, objektifikasi atau objectification merupakan kata benda yang menunjukan makna proses atau upaya seperti kata islamisasi/islamization yang dipopulerkan oleh Syed Naqaib alAtas dan Isma'il Raji al-Faruqi (Sholeh, 2017: 210). Kuntowijoyo sendiri tidak menjelaskan secara spesifik definisi secara bahasa dari objektifikasi. Menuntutnya objektifikasi berasal dari kata objektif yang artinya the act objectifying (membuat sesuatu menjadi objektif) (Kuntowijoyo, 2006: 73). Kuntowijoyo memulai pembicaraannya dengan memenjelaskan mengenai perbuatan objektif.

Suatu perbuatan disebut objektif jika perbuatan tersebut dapat dirasakan oleh pihak lain sebagai hal yang wajar, bukan sebagai perbuatan keagamaan. Sebagai contoh, jika seseorang berbelanja atau menonton film, seseorang akan cenderung untuk memilih produk yang berkualiatas dengan harga yang murah. Kegiatan berbelanja dengan mencari produk yang berkualitas dan dengan harga murah merupakan suatu perbuatan objektif yang cenderung akan dilakukan oleh setiap konsumen manapun (Kuntowijoyo, 1997: 62) Contoh lainnya adalah sopir angkot, pelayan toko, pegawai kantor pos, teller bank dan lain sebagainya tidak pernah menanyakan siapa yang datang tetapi mereka langsung melayani begitu saja tanpa membedakan agama orang yang satu dengan yang lainnya (Kuntowijoyo, 2006:66).

Objektifikasi dalam pandangan Kuntowijoyo (2006: 61) merupakan penerjemahan nilai-nilai internal ke dalam kategori-kategori objektif. Objektifikasi bermula dari internalisasi nilai, tidak dari subjektifikasi kondisi objektif sehingga ada pokok perbedaan yang jelas antara objektifikasi dan sekulerisasi. Jadi, objektifikasi Islam artinya penerjemahan nilai-nilai

al-ạ̣kām Vol. 3, Nomor 1, 2018 
Islam yang telah diserap kedalam struktur kesadaran internal ke dalam bentuk-bentuk yang objektif. Islam yang semula berupa nilai-nilai yang bersifat subjektif, dengan objektifikasi ditransformasikan menjadi nilai-nilai objektif (Munajat, 2009: 242-243). Skema berikut akan menjelaskan kedudukan objektifikasi di tengah-tengah terminologi lain, yaitu internalisasi, eksternalisasi, subjektifikasi dan gejala objektif.

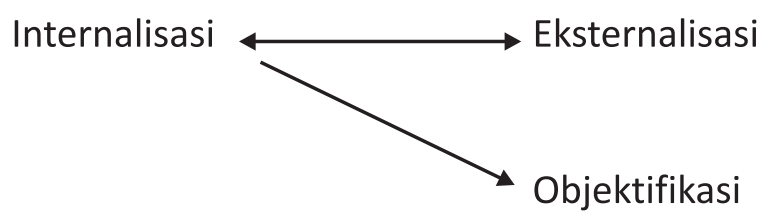

Subjektifikasi $\longleftrightarrow$ Gejala Objektif

Gambar 1:Proses Objektifikasi

Tulisan ini akan menyebutkan eksternalisasi bila merupakan konkretisasi dari keyakinan yang dihayati secara internal. Contohnya adalah pembayaran zakat dari seorang muslim. Zakat timbul setelah adanya keyakinan tentang perlunya harta dibersihan. Keyakinan bahwa sebagian harta itu bukan milik orang yang mendapatkan, dan keyakinan bahwa rizki itu harus dinafkahkan. Kalau kemudian orang membayar zakat, maka itu disebut sebagai eksternalisasi. Jadi ekternalisasi adalah ibadah (Kuntowijoyo, 2006: 62).

Objektifikasi menempuh prosedur yang sama dengan eksternalisasi, tetapi terdapat tambahan. Objektifikasi juga merupakan kongkritisasi dari keyakinan internal. Suatu perbuatan disebut objektif bila perbuatan itu dirasakan nonmuslim sebagai sesuatu yang sewajarnya, tidak sebagai perbuatan keagamaan. Sekalipun demikian, dari sisi yang melakukan perbuatan bila tetap menganggapnya sebagai perbuatan keagamaan, maka termasuk amal. Objektifikasi dapat dilakukan oleh siapapun dari golongan apapun asalkan hal tersebut dapat disepakati oleh pihak lain sebagai sesuatu yang apa adanya dan berlaku sewajarnya, sekalipun dari pihak yang bersangkutan menganggapnya sebagai sesuatu yang berasal dari keyakinan yang ia pegang (Kuntowijoyo, 2006: 62). Objektifikasi akan dapat dinikmati oleh siapapun tanpa harus menyetujui nilai-nilai asal karena objektifikasi merupakan perbuatan rasional-nilai (wertrational) yang diwujudkan dalam bentuk perbuatan rasional. Misalnya, kewajiban yang dibebankan Tuhan kepada umat Islam untuk melindungi dan membantu kaum lemah dan tertindas dapat diobjektifikasikan dengan Inpres Desa Tertinggal atau bantuan subsidi pangan dalam bentuk raskin (Kuntowijoyo, 1997: 68-69).

Munfarida (2015: 145) menjelaskan bahwa sebenarnya, dalam konteks di Indonesia, objektifikasi ini sudah dilakukan oleh para tokoh agama sejak dulu, namun belum ada 
tokoh yang merumuskan teori objektifikasi, terutama ketika menetapkan pancasila sebagai dasar Negara. Ketika merumuskan silanya serta ketika membuat undang-undang dasar. Sila pertama dalam Pancasila misalnya, berasal dari konsep tauhid umat Islam yang diobjektifikasikan dalam Pancasila sehingga dapat diterima oleh semua umat beragama di Indonesia tanpa harus menyetujui nilai-nilai asalnya dan umat Islam dapat mengakui bahwa negara Indonesia dengan pancasilanya merupakan negara yang berlandaskan prinsip tauhid.

Objektifikasi akan menghindarkan masyarakat dari dominasi kelompok tertentu. Hal yang sangat dikhawatirkan oleh nonmuslim adalah bahwa Islam yang merupakan agama penduduk mayoritas akan sangat dominan sehingga tidak ada ruang gerak bagi agama lain. Untuk menghindari adanya dominasi dan subordinasi ini, objektifikasi dapat dijadikan jawaban dan jalan tengah. Objektifikasi akan menjamin kesamaan agama-agama dalam pembangunan hukum nasional sehingga menghilangkan kekhawatiran terhadap dominasi kelompok mayoritas dan tercapainya kestabilan nasional. Karena itu, ungkapan menghukumi dengan hukum Allah harus diobjektifikasikan dalam sejumlah peraturan perundangan, peraturan pemerintah dan lainya (Kuntowijoyo, 2006: 62-64).

Dengan objektifikasi, hukum Islam dipahami tidak dalam kerangka formal tetapi substantif. Objektifikasi Islam adalah konsep yang mendasarkan diri pada sebuah analisis sosial empiris bukan dari analisis yang bersifat tekstual (Kuntowijoyo, 1997: 73). Objektifikasi hukum Islam tetap menjadikan Alquran sebagai dasar hukumnya tetapi agar dapat diterima oleh umat beragama lain, hukum Islam harus diobjektifikasikan terlebih dahulu sehingga dapat dijadikan sebagai hukum nasional yang dapat diterima oleh semua umat beragama di Indonesia (Kuntowijoyo, 2006: 63-64).

\section{Qișāș dan Diyat dalam Ajaran Internal Islam}

Qișāș diambil dari kata qașșa al-aṡar yang berarti mengikuti bekas (al-Jazīri: 2003, 219). Ada juga yang melihat pada sisi subsansi yang menyatakan bahwa qișāș bermakna mumāṡalah yang berarti penyetaraan (Dib al-Bigā: t.t, 196). Dalam gramatika Bahasa Arab, ini disebut dengan faidah musyārakah Berarti maksud dari qișāṣ adalah apa yang dilakukan seseorang pada orang lain, dibalas sama dengan yang dilakukan orang tersebut pada orang lain itu. Dengan demikian, bunuh dibalas bunuh (al-nafs bi al-nafs), melukai mata dibalas melukai mata (al-'ain bi al-'ain), melukai hidung dibalas dengan melukai hidung (al-anf bi al-anf), melukai telinga dibalas dengan melukai telinga (al-udzun bi al-udzun), merusak gigi dibalas dengan merusak gigi (al-sinn bi al-sinn), dan seterusnya. Adapun diyat merupakan sejumlah harta yang wajib diserahkan kepada keluarga korban pembunuhan karena tindak kriminal yang dilakukan terhadap jiwa (al-Zuhaili, 1985:295).

al-ạ̣kān Vol. 3, Nomor 1, 2018 
Qișāș dan diyat tetap dalam syarak berdasarkan dilālah al-ibārah dari QS al-Baqarah (2): 178.

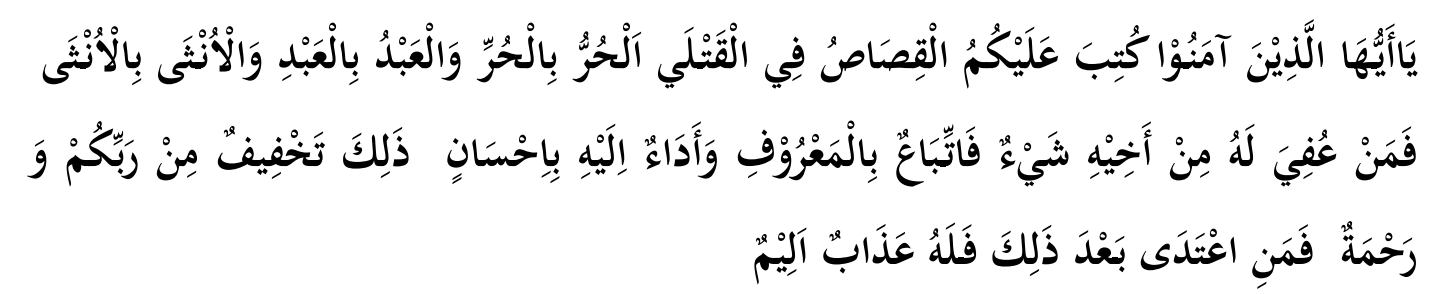

Wahai orang-orang yang beriman! Diwajibkan atas kamu (melaksanakan) qiṣāṣ berkenaan dengan orang yang dibunuh. Orang merdeka dengan orang merdeka, hamba sahaya dengan hamba sahaya, perempuan dengan perempuan. Tetapi barang siapa memperoleh maaf dari saudaranya, hendaklah dia mengikutinya dengan baik dan membayar diyat (tebusan) kepadanya dengan baik (pula). Yang demikian itu adalah keringanan dan rahmat dari Tuhanmu. Barang siapa melampaui batas setelah itu, maka ia akan mendapat azab yang sangat pedih.

Qișāș juga tetap berdasarkan ijmak umat ini tanpa adanya pertentangan. Tetapnya qișās juga didukung pemikiran yang rasional bahwa sesungguhnya harta tidak pantas dijadikan sebagai tebusan pembunuhan sengaja karena tidak adanya kesetaraan. Di dalam qișās juga terdapat hikmah tambahan yaitu kemaslahatan umat karena dapat memberi mereka rasa takut untuk melakukan pembunuhan dan dapat memulihkan perasaan ahli waris (al-Jazīri 2003: 222).

Semua ulama sepakat bahwa qișāṣ diberlakukan untuk pembunuhan yang dilakukan secara sengaja sedangkan diyat merupakan hukuan pengganti dari qișāṣ ketika qiṣāṣ gugur dan merupakan hukuman asal dari selain pembunuhan sengaja. Syafiiah menambahkan kafarat sebagai hukuman tambahan pembunuhan sengaja (al-Zuhaili, 1985:295). Kalangan ulama sendiri berbeda pendapat dalam mengelompokan jenis-jenis pembunuhan. alZuhaili (1985:211-224) mengatakan bahwa mayoritas ulama yaitu Syafiiah dan Hambaliah membagi pembunuhan menjadi 3 yaitu pembunuhan sengaja, pembunuhan semi sengaja, dan pembunuhan tidak sengaja. Malikiah memilih membagi pembunuhan menjadi 2 yaitu pembunuhan sengaja dan tidak sengaja karena nas Alquran hanya mengatakan 2 hal ini. Adapun Hanafiah membagi pembunuhan menjadi 5, yaitu pembunuhan sengaja (al-qatl al-'amd), pembunuhan semi sengaja (al-qatl syibh al-'amd), pembunuhan tidak sengaja (al-qatl al-khața'), pembunuhan yang dihukumi seperti pembunuhan tidak sengaja ( $m \bar{a}$ ujriya mujrā al-khața'), dan pembunuhan karena membuat sebab (al-qatl bi al-tasabbub). Dalam pembahasan selanjutnya, al-Zuhaili memilih menggunakan kategorisasi yang dibuat mayoritas ulama. 
Istilah sengaja dan tidak sengaja merujuk pada pekerjaan hati sedangkan pekerjaan hati bukanlah sesuatu yang jelas (zāhir). Dalam metodologi hukum Islam, atribut yang sifatnya samar tidak bisa dijadikan sebagai gantungan hukum (al-manāț). Oleh karena itu, ulama mensyaratkan al-manāț harus bersifat jelas (ẓāhir) (Khalāf, t.t: 68-69). Batasan kesengajaan dalam pembunuhan adalah pelaku menggunakan alat yang memang bisa menyebabkan kematian (secara umum) seperti menggunakan senjata tajam. Alat inilah yang dijadikan sebagai petunjuk dari adanya kesengajaan yang sifatnya samar (al-Zuhaili, 1985:211).

Pemberlakuan qișāṣ dalam pembunuhan harus memenuhi beberapa syarat yang mencakup syarat pembunuh (al-qātil), syarat terbunuh (al-maqtūl), syarat tindak pembunuhan (nafs al-qatl), dan syarat wali terbunuh (waly al-qātil). Pembunuh disyaratkan harus balig dan berakal, sengaja dalam membunuh dan pembunuhan bersifat murni. Hanafiah menambahkan satu syarat lagi yaitu pembunuh melakukannya atas kehendak sendiri (al-Zuhaili, 1985: 265-266). Jika melihat perbandingan ini, tampaknya syarat yang dibuat oleh Hanafiah lebih bisa diterima akal karena sangat tidak adil jika seseorang dihukum qișāṣ sedangkan dia membunuh tidak atas kehendaknya sendiri.

Adapun syarat dari terbunuh adalah dia merupakan orang yang dilindungi darahnya (ma'șūm al-dam). Contoh orang yang tidak dilindungi darahnya adalah pemberontak (albāgi), orang zindiq (al-zindīq), dan pezina muhsan (al-zāni al-muhșan). Syarat selanjutnya adalah orang yang terbunuh bukan merupakan anak dari pembunuh, dan harus adanya kesetaraan antara terbunuh dan pembunuh dalam hal kemerdakaan dan agama. Demikian pendapat mayoritas ulama. Sementara itu, Hanafiah lebih menunjung aspek egaliter dengan mencukupkan kesetaraan sebagai sama-sama manusia. Dengan demikian, seorang muslim diqișās sebab membunuh budak dan orang kafir dzimmi/mu'āhid, (al-Zuḥaili, 1985: 269).

Adapun syarat dari perbuatan pembunuhan itu sendiri adalah pembunuhan yang dilakukan secara langsung (al-mubāsyarah) misalnya dengan menusuk korban, bukan pembunuhan yang dilakukan dengan cara membuat sebab (al-tasabbub) seperti membuat lubang di tengah jalan yang berakibat matinya seseorang, demikian pendapat Hanafiah sedangkan Jumhur tidak mensyaratkan itu (al-Zuhaili, 1985: 273).

Syarat terakhir adalah syarat dari wali korban, yang merupakan pemilik hak qiṣās, diketahui. Ketika wali korban tidak diketahui, menurut Hanafiah qișās tidak diberlakukan. Pendapat ini bertentangan dengan mayoritas ulama yang tidak menyaratkan diketahuinya wali. Ketika semua syarat ini terpenuhi, maka qișās diberlakukan (al-Zuhaili, 1985: 274).

Menurut Hanafiah dan Hambaliah dalam pendapat yang paling sahih, qișās dilakukan menggunakan pedang sedangkan menurut Syafiiah dan Malikiah, qișās dilakukan menggunakan alat seperti saat pembunuhan dilakukan. Jika eksekusi diganti dengan menggunakan pedang, maka itu lebih utama karena telah keluar dari perbedaan pendapat.

al-ạ̣kām Vol. 3, Nomor 1, 2018 
Akan tetapi, ketika pembunuhan dilakukan dengan cara yang haram seperti sihir, mencekoki arak, dan lain sebagainya, maka pedang menjadi alat yang dipilih (al-Zuhaili, 1985:282-283). al-Zuhaili menambahkan, dengan melihat alasan penggunaan pedang adalah karena pedang merupakan alat yang paling cepat mematikan dan paling mudah dalam penebusan dosa/ kesalahan (pada zaman dahulu), boleh saja digunakan alat lain yang lebih cepat mematikan dan lebih bisa terhindar dari al-muślah (menghukum karena balas dendam) seperti alat pemenggal kepala, kursi listrik yang cepat dalam mematikan, dan tali gantung karena alatalat ini tidak mengalirkan darah (al-Zuḥaili, 1985:285).

Diyat merupakan sanksi wajib pengganti qișās menurut Hanabilah, atau ketika dimaafkan oleh keluarga korban menurut Syafiiah, dan berdasarkan kerelaan dari pembunuh menurut Hanafiah dan Malikiah.Selain diyat, takzir juga merupakan sanksi penggganti yang wajib menurut Malikiah sedangkan Jumhur berpendapat bahwa takzir diserahkan pada keputusan hakim. Menurut Malikiah, Takzir bagi pembunuh sengaja adalah 100 kali jilid dan penjara satu tahun (al-Zuḥaili, 1985: 213).

Harta yang diserahkan sebagai diyat menurut Abū Ḥanīfah, Mālik, dan al-Syāfi'i dalam al-qaul al-qādim adalah 100 ekor unta, 1000 dinar (emas), atau 10.000 dirham (perak). Sedangkan Aḥmad memberikan 6 opsi yaitu unta, emas, perak, sapi, kambing, dan hullah. Diyat pembunuhan sengaja ini, berdasarkan kesepakatan ulama, diwajibkan bagi pembunuh sendiri, buka 'āqilah. Selain itu, diat ini harus segera diserahkan oleh pihak pembunuh kepada keluarga korban.(al-Zuḥaili, 1985:300-308).

Menurut Syafiiah dan Hambiliah, nominal diyat pembunuhan sengaja adalah sebagaimana nominal yang disebutkan hadis yaitu 100 unta namun ketika pembunuh tidak menemukan baik karena uzur syar'i maupun hissi maka diat beralih kepada nilai dari 100 ekor unta. Hanafiah dan Malikiah lebih menjunjung asas musyawarah dengan menyerahkan kesalingrelaan antara pihak pembunuh dengan keluarga korban, namun ketika keduanya tidak menentukan maka diatnya adalah 100 ekor unta (al-Zuḥaili, 1985:309).

Dalam pembunuhan sengaja dan semi sengaja menurut mayoritas ulama berlaku pemberatan diyat sehingga diyatnya disebut diyat mugallazah. Dalam pembunuhan sengaja, diyat merupakan hukuman pengganti sedangkan dalam pembunuhan semi sengaja diyat merupakan hukuman pokok karena tidak ada qiṣās dalam jenis pembunuhan ini. Pemberatan ini berlaku ketika harta yang diserahkan sebagai diyat berupa unta sedangkan harta diyat lain seperti dinar dan dirham tidak berlaku karena nas tidak menyinggungnya dan tidak ada tempat bagi rasio untuk hal-hal yang bersifat muqaddarāt (yang sudah ditentukan kadarnya) (Khalaf, t.t: 34). Sementara itu, Malikiah yang menafikah jenis pembunuhan semi pengaja berpendapat bahwa pemberatan diyat berlaku pada pembunuhan sengaja ketika wali korban menerimanya dan pembunuhan orang tua terhadap anaknya. Diyat mugallazah menurut Syafiiah dan Malikiah berupa 30 hiqqah, 30 jada'ah, dan 40 khalifah (unta hamil) 
sedangkan menurut Hanafiah dan Hambaliah berupa 25 bint makhāḍ, 25 bint labūn, 25 hiqqah, 25 jada'ah (al-Zuhaili, 304-305).

Diyat dalam pembunuhan semi sengaja ini sama persis dengan diyat pembunuhan sengaja dalam jenis, nominal, dan pemberatannya. Hanya saja, diyat pembunuhan jenis ini dibebankan kepada āqilah dan penyerahannya diperpanjang waktunya hingga 3 tahun yang penyerahannya dilakukan setiap akhir tahun. Menurut Hanafiah, permulaan tahun dihitung sejak keputusan hukum ditetapkan sedangkan menurut Syafiiah dan Hambaliah permulaan tahun dihitung sejak pembunuhan itu dilakukan (al-Zuhaili, 1985:319). Ketika diyat gugur karena alasan tertentu, menurut Malikiah hukuman beralih ke takzir. Menurut mereka, hakim menentukan takzir yang sesuai dengan kesalahannya. Sementara itu, mayoritas ulama meninggalkan pilihan bagi hakim dalam memberikan takzir kepada pelaku pembunuhan semi sengaja ini (al-Zuḥaili, 1985:327).

$\bar{A} q i l a h$, penanggung diat, secara bahasa berasal dari kata $a q l$ (mencegah). Ini berarti āqilah yang merupakan ism fä'il bermakna pencegah karena ia dapat mencegah dari dialirkannya darah. Menurut Hanafiah, āqilah merupakan anggota dewan yaitu tentara dan laskar yang nama-namanya dicatat dalam pembukuan. Diyat ini diambil dari gaji mereka. Jika pembunuh bukan termasuk dari anggota dewan maka āqilah adalah kabilah, kerabat dan setiap orang yang saling tolong-menolong dengannya. Sementara itu, Mayoritas ulama berpendapat bahwa āqilah merupakan kerabat pembunuh dari jalur ayah/'așabah (alZuhaili, 1985:323).

Pendapat Hanafiah ini sebenarnya merujuk pada pendapat dari Sahabat Umar yang telah merubah konsep āqilah di zaman Rasulullah karena melihat pada sisi substansi dan maqāșid. Ini dilakukan setelah kodifikasi dewan. Substansi dari pembebanan diyat pada ăqilah adalah tolong-menolong. Pada zaman Rasulullah tanggung jawab sosial dalam hal tolong-menolong ada pada kerabat dari jalur bapak baik itu kabilah ataupun keluarga. Ketika Umar membentuk dewan, bisa diketahui bahwa prajurit di suatu kota pasti akan tolong-menolong meskipun mereka bukan kerabat. Āqilah bisa berubah seiring perubahan kondisi. Dengan latar belakang ini, al-Qaraḍāwi (2005: 82) memberikan sebuah fatwa progresif dengan mengatakan bahwa āqilah di zaman sekarang berubah menjadi asosiasi sebuah pekerjaan, misalnya asosiasi dokter merupakan āqilah dari dokter, asosiasi insinyur merupakan āqilah dari insinyur dan lain sebagainya.

Selain diyat, sanksi asal dari tindak pembunuhan semi sengaja menurut mayoritas ulama selain Malikiah adalah kafarat. Kafarat yang harus dikerjakan adalah memerdekakan budak mukmin. Ketika tidak menemukan, maka kafaratnya adalah puasa dua bulan secara berturut-turut. Sementara itu, Malikiah yang menafikan jenis pembunuhan semi sengaja berpendapat bahwa pembunuhan yang dalam klasifikasi mayoritas ulama dimasukan ke dalam jenis pembunuhan semi sengaja tidak wajib kafarat (al-Zuhaili, 1985:327).

al-ạ̣kān Vol. 3, Nomor 1, 2018 
Pembunuhan tidak sengaja merupakan pembunuhan tanpa disertai niatan dari pembunuh. Sebagai contoh, seseorang yang berniat memanah burung namun mengenai orang lain sehingga meninggal (al-Zuḥaili, 1985:223). Sanksi dari pembunuhan jenis ini adalah diyat dan kafarat. Dalam jenis ini tidak ada takzir yang bertujuan memberi efek jera karena memang pembunuhan dilakukan tanpa adanya niat. Pembunuhan dengan jalan membuat sebab (tasabbub) menurut mayoritas ulama sama dengan pembunuhan tidak sengaja. Adapun Hanafiah berpendapat bahwa hukuman pembunuhan dengan membuat sebab adalah hanya diyat tanpa kafarat. Dalam kedua jenis pembunuhan ini diyat dibebankan kepada āqilah (al-Zuḥaili, 1985:328).

Diyat yang dikeluarkan dalam pembunuhan tidak sengaja, jika yang dikeluarkan unta, adalah 20 bint makhāḍ, 20 ibn Makhāḍ, 20 bint labūn, 20 hiqqqah, dan 20 jada'ah. Sementara itu, Syafiiah dan Malikiah menjadikan 20 bani labūn di tempat 20 bani makhāḍ. Pemberian tenggang waktu dalam diyat bagi Hanafiah berlaku bagi pembunuh dan āqilah sedengakan mayoritas ulama berpendapat bahwa pemberian tenggang waktu hanya berlaku bagi āqilah karena prinsip dari diyat yang dikeluarkan āqilah adalah pertolongan bagi pembunuh. Adapun penyerahan diyat dari pembunuh wajib penyegeraannya karena diyat ini adalah sebagai ganti rugi dari barang yang dirusak (al-Zuhaili, 1985:328-329).

\section{Objektivikasi Qiṣāṣ dan Diyat: Mengindonesiakan dan Mempositifkan Fikih Jinayat}

Aktualisasi, formalisasi, dan/atau positivisasi ajaran agama Islam di Indonesia telah dilakukan. Ini dilakukan dengan dua jalan yaitu eksternalisasi dan objektifikasi. Eksternalisasi pada intinya adalah kongkritisasi dari keyakinan atau ajaran yang dihayati namun kongkritisasi ini belum sampai kepada tataran dapat dinikmati oleh setiap orang baik muslim maupun nonmuslim. Contoh kongkritisasi dalam konteks di Indonesia adalah penyusunan Kompilasi Hukum Islam (KHI) yang merupakan acuran standar perkawinan muslim di Indonesia. KHI merupakan susulan dari UU No. 1 Tahun 1974 yang dalam Pasal 2 dari undang-undang ini menyebutkan bahwa perkawinan harus dilakukan sesuai agama dan kepercayaan masingmasing. Contoh lain adalah mengenai pengelolaan zakat di Indonesia. Pengelolaan zakat di Indonesia diatur dalam UU No. 23 Tauhun 2011. Dua contoh tersebut merupakan produk ekternalisasi karena tidak bisa dinikmati oleh nonmuslim.

Adapun objetifikasi merupakan konkritisasi suatu ajaran namun bisa dirasakan oleh semua orang baik muslim maupun nonmuslim. Secara umum, bentuk objektifikasi dari ajaran agama Islam dalam konteks di Indonesia dapat dipetakan menjadi 2 yaitu obektifikasi substantif dan objetifikasi teknis. Objektifikasi substantif berarti ajaran yang diobjektifkan untuk dinikmati semua orang adalah intisari atau substansinya saja seperti objektifikasi doktrin tauhid (qul quwa Allah ahad) yang menghasilkan sila "Ketuhanan Yang Maha Esa" sehingga setiap warga negara dapat bebas beragama asalkan menyembah Tuhan Yang Esa. 
Begitu pula empat sila lain yang merupakan bentuk objektifikasi dari nilai dan ajaran Islam.

Objektifikasi teknis merupakan objektifikasiyang tidak hanya mengambil substansinya saja tetapi mencakup teknisnya. Kita bisa mengambil contoh, sebagaimana Kuntowijoyo sebutkan dalam buku Islam sebaga IImu, bank syariah dan BMT. Setiap orang baik muslim maupun nonmuslim bisa menikmati pelayanan dari lembaga keuangan syariah meskipun lembaga-lembaga ini masih menggunakan istilah-istilah dalam Islam seperti syariah, murābahah, muḍārabah, wadīah dan lain sebagainya. Pegawai dari lembaga keuangan syariah ini juga tidak membedakan nasabah yang datang apakah dia muslim atau bukan.

Berkaitan dengan uqūbah dalam Islam yaitu qișāș, diyat, kafārah, dan takzir, objektifikasi bisa dilakukan dalam jenis yang kedua yaitu objektifikasi teknis karena pada dasarnya teknis dan pelaksanaan qiṣāṣ dapat dilaksanakan di Indoesian namun harus disesuaikan dengan keadaan obejektif di Indonesia. Pertanyaan yang muncul adalah teknis seperti apa yang tepat diterapkan di Indonesia sedangkan interpretasi mengenai qișāș dan diyat berbeda di antara madzab-madzab dalam Islam. Berdasarkan teori yang telah disajikan di poin Qișāș dan Diyat dalam Ajaran Internal Islam pemahaman Hanafiah lebih sesuai dengan kondisi di Indonesia.

Hanafiah memberikan kontribusi pemikiran mengenai qișāș dan diyat yang lebih rasional dibanding madzab-madzab lain. Selain itu, Hanafiah menjunjung tinggi asas egalitarianisme. Ini berbeda dengan Malikiah, Syafiiah, dan Hambaliah yang mensyaratkan adanya kesetaraan dalam agama dan kemerdekaan untuk pemberlakuan qișāș. Ketika seorang muslim membunuh orang nonmuslim, menurut 3 madzab ini qișāș tidak diberlakukan karena Islam dinilai lebih tinggi derajatnya daripada agama lain sedangkan menurut Hanafiah qișāṣ tetap diberlakukan karena tidak mensyaratkan adanya kesetaraan dalam agama. Tentu saja, ini sangat sesuai dengan kondisi objektif di Indonesia yang pluralis. Dengan demikian, sebagai sebuah tawaran pembaharuan, penulis mewarkan qișāș dan diyat versi Hanafiah untuk diobjektifkan dan dipositifkan.

Meskipun demikian, penulis tidak menafikan metode talfiq dalam objektifikasi qișāș dan diyat untuk kemudian dipositifkan. Metode talfiq telah digunakan dalam ektrernalisasi hukum perkawinan/pernikahan Islam sehingga menghasilkan Kompilasi Hukum Islam yang menjadi rujukan pokok dari hukum perkawinan di Indonesia (Nuroniyah, 2016: 35). Berkaitan dengan kafārah, penulis lebih sepakat untuk menjadikan kafārah sebagai hukum yang dikembalikan kepada masing-masing individu dan tidak dipositifkan karena kafārah sendiri merupakan bentuk peribadatan dan upaya pembunuh untuk melebur, menghapus dan menutup (kafara/cover) dosanya (al-Jazīri, 2003: 246).

Qișāș yang memungkinkan untuk diobjektifkan baik intisari maupun teknis pelaksanaannya harus dilakukan dengan disertai penggantian istilah qișāș yang terkesan eksklusif dengan istilah yang bersifat inklusif dan universal sehingga dapat diterima oleh

al-ạ̣kām Vol. 3, Nomor 1, 2018 
semua orang baik muslim maupun nonmuslim. Dalam peraturan perundang-undang, kita bisa menggunakan istilah hukuman mati. Ini merupakan solusi agar pembaharuan hukum ini lebih dikenal sebagai pemberatan hukuman bukan sebagai islamisasi atau syariatisasi. Dengan demikian, qișās akan diterima oleh semua orang.

Agar tidak dinilai sebagai islamisasi atau syariatisasi dan dapat diterima semua orang, penulis mengusulkan agar eksekusi hukuman mati terhadap pembunuh dilakukan sebagaimana hukuman mati dari tindak pidana lain yaitu dengan cara ditembak oleh regu yang terdiri dari seorang bintara, 12 orang tamtama, dan di bawah pimpinan seorang perwira. Teknis hukuman mati bagi pembunuh sengaja harus merujuk pada UU No. 2 PNPS 1964 tentang Tata Cara Pelaksanaan Pidana Mati dan Peraturan Kapolri No. 12 Tahun 2010 tentang Tata Pelaksanaan Pidana Mati. Hukuman mati dengan cara seperti ini merupakan hukuman mati yang paling sesuai dengan kondisi objektif di Indonesia daripada hukuman pancung seperti yang dilaksanakan di Arab Saudi. Dengan demikian, hukuman mati dari pembunuhan sengaja tidak merubah tradisi/urf yang telah berpuluh-puluh tahun berlaku.

Teknis pelaksanaan qiṣāṣ dalam fikih tradisional dilakukan di depan umum (Darussamin, 2014: 126). Ini bertujuan agar orang-orang yang tidak membunuh menyaksikan dan mengambil pelajaran sehingga mereka tidak melakukan tindak pembunuhan. Dalam terminologi hukum, ini disebut sebagai tujuan prevensi umum/generale preventie (Moering, 2012: 224). al-Qaraḍāwi (2008: 197) mengatakan bahwa wasīlah untuk mencapai tujuan bisa berubah seiring perubahan kondisi, waktu, tradisi dan faktor-faktor lain bahkan menurutnya dalam kondisi tertentu wasillah terkadang harus diganti. Melihat konteks di Indonesia, hukuman mati dengan disaksikan orang banyak bukan sesuatu yang lazim dan jika dilakukan akan menyalahi tradisi/urf yang telah berlaku. Berdasarkan latar belakang ini, penulis mengusulkan eksekusi di depan umum tidak diterapkan tetapi diganti dengan publikasi melalui media elektronik seperti televisi atau media cetak seperti surat kabar. Bahkan, publikasi melalui media lebih efektif karena bisa disaksikan atau diketahui oleh seluruh warga Indonesia. Dengan demikian tujuan generale preventie bisa tercapai.

Diyat sebagai hukuman pengganti qiṣāș atau sebagai hukuman asal dari pembunuhan semi sengaja, tidak sengaja, yang diserupakan dengan tidak sengaja, dan dengan membuat sebab juga harus diobjektifkan dengan menggunakan bahasa yang bersifat universal. Penulis mewarkan istilah kompensasi. Selama ini, sanksi-sanksi dalam KUHP berupa penjara, hukuman mati dan denda. Bentuk sanksi-sanksi ini menjadikan KUHP sebagai hukum yang bersifat individual. Keluarga korban seolah tidak berarti apa-apa di depan hukum sedangkan mereka sebenarnya membutuhkan bantuan. Sebagai contoh, ada sebuah keluarga yang kepala keluarganya menjadi korban pembunuhan sedangkan dia merupakan tulang punggung keluarga, jika pelaku pembunuhan hanya dihukum penjara, maka sebenarnya hukuman tersebut hanya bersifat retributif (balasan) saja namun tidak 
menyelesaikan permasalahan yang diterima keluarga korban. Dengan adanya kompesasi terhadap keluarga, permasalahan yang menimpa keluarga korban bisa terobati dari sisi ekonomi.

Kompesasi yang diberikan kepada keluarga korban mengikuti aturan dan tata cara yang dibuat Hanafiah baik mengenai barang yang diserahkan, waktu penyerahan, penanggung kompensasi dan lain sebagainya dengan alasan yang telah penulis sebutkan dalam paragraf sebelumnya. Berkaitan dengan nominal kompensasi, penulis sepakat dengan Hanafiah dan Malikiah bahwa nominal kompensasi ditentukan berdasarkan musyawarah dari keluarga korban dan pembunuh. Namun dalam hal ini, pemerintah harus menentukan batas minimal dan batas maksimal dari nilai kompensasi ini sebagai upaya pencegahan (sadd al-dzarīah) dari hal-hal yang bisa merugikan salah satu pihak. Mengingat nilai mata uang tidak bersifat tetap atau bahkan terjadi inflasi, nominal batas minimal dan maksimal dari kompensasi terbuka untuk diperbaharui. Ini seperti yang telah terjadi dalam KUHP. Sebelum diubah, ancaman hukuman pasal 303 KUHP berkaitan dengan perjudian adalah hukuman penjara maksimal 2 tahun 8 bulan atau denda maksimal Rp. 90.000,- namun setelah diubah dengan keluarnya UU No. 7 Tahun 1974, ancaman hukuman menjadi hukuman penjara maksimal 10 tahun atau denda maksimal Rp. 25.000.000,--. Perubahan juga terjadi dalam pasal 542 (Muljanto, 2008: 215).

Dalam objektifikasi, formalisasi, dan positivisasi diyat, penulis sepakat dengan alQaraḍāwi bahwa penanggung kompensasi dalam pembunuhan semi sengaja, tidak sengaja, seperti tidak sengaja, dan kerena membuat sebab dilimpahkan pada persatuan atau ikatan pekerjaan tertentu. Melihat konteks di Indonesia, penanggung kompensasi dari guru adalah PGRI (Persatuan Guru Republik Indonesia), penanggung kompensasi dari dokter adalah IDI (Ikatan Dokter Indonesia), dan lain sebagianya. Dengan aturan ini, pembayaran kompensasi akan terasa ringan mengingat anggota dari ikatan persatuan pekerjaan banyak.

Hukuman bagi pembunuh selain hukuman mati dan kompensasi terhadap keluarga korban adalah takzir. Takzir merupakan hukuman yang diberikan kepada pembunuh atau pelaku kesalahan lainnya yang tidak ditunjukan tata caranya oleh nas. Subsansi dari takzir adalah membuat jera. Takzir ini sepenuhnya diserahkan sepenuhnya kepada hakim karena nas tidak menuntunnya secara pasti.

Objektifikasi qișāṣ dan diyat untuk kemudian dipositifkan sebagai pengganti hukum yang diterangkan dalam BAB XIX dari KUHP tentang kejahatan terhadap nyawa merupakan suatu langkah dekonstruksi dan rekonstuksi hukum sekaligus. Ini mengingat antara uqūbah islāmiyyah dengan sanksi dalam KUHP terdapat banyak perbedaan. Diantara perbedaannya adalah hukum yang merujuk pada KUHP bersifat individual dalam arti sanksi yang dibebankan hanya terpusat pada pelaku kriminal tanpa mempedulikan keluarga korban (Bahiej, 2006: 16) sedangkan qișāṣ-diyat mempertimbangkan dan memperhatikan keluarga korban 
sebagai penentu akan diberlakukan qișāṣ atau diyat. Ini yang Ali Sodiqin (2015: 68) sebut sebagai restorative justice yang artinya suatu alternatif penyelesaian masalah pidana dengan penekanan pada pemulihan masalah dan pengembalian keseimbangan dalam masyarakat. Tindak pidana dianggap sebagai suatu konflik sosial yang harus diselesaikan oleh semua pihak. Perbedaan lainnya adalah hukuman kurungan dan qișāș sama-sama hukuman pokok namun status hukuman pokok dari qișāș bisa diganti diyat ketika pembunuh mendapat maaf dari keluarga korban (Darussamin, 2014: 125). Selain itu, jenis-jenis pembunuhan dan bentuk sanksinya yang disebutkan dalam BAB XIX KUHP pasal 338-350 sangat berbeda dengan jenis-jenis pembunuhan dan sanksinya dalam Islam. Oleh karena itu, penggantian dari KUHP tentang kejahatan terhadap nyawa dengan qișāș-diyat merupakan dekonstruksi sekaligus rekonstruksi hukum.

\section{Simpulan}

Objektifikasi qișāṣ dan diyat merupakan langkah progresif dalam upaya pembaharuan hukum pidana di Indonesia yang usang, tidak efektif, dan individual. Qișāș dan diyat telah terbukti mampu menjalankan fungsi sebagai social control dan social engineering. Objektifikasi qișāș dan diyat dilakukan dengan menyesuaikan keduanya dengan keadaan objektif di Indonesia dan mengganti istilah keduanya dengan bahasa yang inklusif dan universal. Istilah qișāṣ diganti dengan istilah hukuman mati. Istilah diyat diganti dengan istilah kompensasi terhadap keluarga korban. Dengan dua cara langkah ini, qișāș dan diyat dapat diterima oleh semua warga Indonesia yang multi kultur dan multi agama.

\section{Daftar Pustaka}

Bahiej, Ahmad. 2006. "Sejarah dan Problematika Hukum Pidana Materiel di Indonesia". Sosio-Religia. Vol.4 No. 4. (2005): 1-21.

Dib al-Bigha, Musţafā. Tadzīb fi Adillah Matn Al- Ghayah wa At- Taqrīb. Surabaya: alHaramain, t.t.

Darussamin, Zikri. "Qisas dalam Islam dan Relevansinya dengan Masa Kini" Asy-Syari'ah. Vo. 48. No. 1. Juni (2014): 99-130.

Echols, John dan Hassan Shadily. Kamus Inggris Indonesia. Jakarta: Gramedia, 2014.

Hadi, M. Khoirul. "Objektifikasi Hukum Perkawinan Islam Di Indonesia Perspektif Maqasid Syar'iyyah Upaya dari Keilmuan Keislaman”. Yudisia. Vol. 7. No. 1. Juni (2016): 199237.

Jamaa, La. "Tantangan Modernitas Hukum Pidana Islam". Ahkam. Vol. XVI. No. 2. Juli (2016):261-272. 
al-Jazīri, Abd al-Raḥmān. Kitāb al-Fiqh 'alā al-Madzāhib al-Arba'ah. Vol.5. Beirut: Dar alKotob al-Ilmiyah, 2003.

Khalāf, Abd al-Wahhāb. 'Ilm Ușūl al-Fiqh. Cairo: Maktabah al-Da'wah al-Islāmiyyah, t.t.

Kuntowijoyo. Identitas Politik Umat Islam. Bandung: Mizan, 1997.

Kuntowijoyo. Islam Sebagai IImu: Epitemologi, Metodelogi dan Etika. Yogyakarta. Tiara Wacana, 2006.

Miftahuddin. Kuntowijoyo dan Pemikirannya: Dari Sejarahwan sampai Cendekiawan. Yogyakarta: Penelitian UNY, 2014.

Moeljanto. KUHP: Undang-undang Hukum Pidana. Jakarta:Bumi Aksara, 2012.

Munajat, Makhrus. Hukum Pidana Islam di Indonesia. Yogyakarta. Teras, 2009.

Munfarida, Elya. "Reinterpretasi Islam Integratif: Objektifikasi Deliberatif Islam di Ruang Publik". Komunika. Vol. 9. No. 1. Januari (2015):131-144.

Reksodiputro, Mardjono. Beberapa Catatan untuk Hukum Pidana Indonesia. Jakarta: Indonesia Jentera, 2016.

Nuroniyah, Wardah. "Kritik Metodologis terhadap Pembaharuan Hukum Perkawinan dalam Kompilasi Hukum Islam”. Mahkamah. Vol. 1 No. 1. Juni (2016): 33-47.

al-Qaraḍawi, Yūsuf. Dirāsah fi Fiqh Maqāșid al-Syarīah: Bain al- Maqāṣid al-Kulliyyah wa alNușūṣ al-Juz'iyyah. Cairo: Dār al-Syurūq, 2008.

Sodiqin, Ali. "Restorative Justice dalam Tindak Pidana Pembunuhan: Perspektif Hukum Pidana Indonesia dan Hukum Pidana Islam" Asy-Syari'ah. Vol 19. No. 1. Junin (2015): 63-100.

Sholeh. "Islamisasi IImu Pengetahuan (Konsep Pemikiran Ismail Raji Al-Faruqi dan Syed Muhammad Naqaib al-Attas)". Al-Hikmah. Vo. 14. No. 2. Oktober (2017): 209-221

Sugiono. Metode Penelitian Pendidikan: Pendekatan Kualitatif, Kuantitatif, dan R\&D. Bandung: Alfabeta, 2007.

Tim Redaksi.6 Kasus Pembunuhan Sadis di Sumsel Sepanjang 2017. (2007). (http://m. liputan6.com/regional/read/3209766/6-kasus-pembunuhan-sadis-di-sumselsepanjang-2017), diakses 19 Maret 2018.

Tim Redaksi. Angka Pembunuhan di Jakarta Meningkat 4 Persen Tahun ini. 2015. (https:// news.detik.com/berita/3107908/angka-pembunuhan-di-jakarta-meningkat-4persen-tahun-ini), diakses 18 Maret 2018.

Tim Redaksi. IPW: Angka Pembunuhan di Januari 2016 Meningkat. (2016). (http:// fokusjabar.com/2016/02/01/ ipw-angka-pembunuhan-di-januari-2016-meningkat, 2016), diakses 19 Maret 2018.

Topo Santoso. Membumikan Hukum Pidana Islam: Penegakan Syariat dalam Wacana dan Agenda. Jakarta: Gema Insani. 2003.

al-Zuhaili, Wahbah. al-Fiqh al-Islāmy wa Adillatuhu. Vol. 6. Damaskus: Dar al-Fikr, 1986. 